\title{
Effects of substitution of beet pulp for barley or corn in the diet of high-producing dairy cows on feeding behavior, performance, and ruminal fermentation
}

\author{
M. Nemati, ${ }^{1}$ F. Hashemzadeh, ${ }^{1}$ G. R. Ghorbani, ${ }^{1}$ E. Ghasemi, ${ }^{1}$ M. Khorvash, ${ }^{1}$ M. H. Ghaffari, ${ }^{2}$ \\ and S. M. Nasrollahi ${ }^{3 *}$ \\ ${ }^{1}$ Department of Animal Science, College of Agriculture, Isfahan University of Technology, Isfahan 84156-83111, Iran \\ ${ }^{2}$ Institute of Animal Science, Physiology and Hygiene Unit, University of Bonn, 53111 Bonn, Germany \\ ${ }^{3}$ Young Researchers Club, Khorasgan (Isfahan) Branch, Islamic Azad University, Isfahan 81595-185, Iran
}

\begin{abstract}
This study investigated the effects of substituting beet pulp (BP) for different grains (barley or corn) in the diet of high-producing dairy cows on intake, feeding behavior, nutrient digestibility, ruminal fermentation, milk production, and feed conversion efficiency. Eight second-parity Holstein cows $(62 \pm 2 \mathrm{~d}$ in milk; milk yield $=54 \pm 1.2 \mathrm{~kg} / \mathrm{d}$; body weight $=624 \pm 26$; all mean $\pm \mathrm{SE}$ ) were used in a replicated $4 \times 4$ Latin square design during 4 periods of $21 \mathrm{~d}$. Cows were randomly assigned to 1 of 4 treatments that were a 2 $\times 2$ factorial arrangement of 2 grain sources (corn or barley) and 2 levels of BP inclusion [5 or $15 \%$ of dry matter (DM)] in the diet: (1) barley-based diet with $\mathrm{BP}$ at $5 \%$ of dietary DM; (2) barley-based diet with $\mathrm{BP}$ at $15 \%$ of dietary DM; (3) corn-based diet with $\mathrm{BP}$ at $5 \%$ of dietary DM; and (4) corn-based diet with $\mathrm{BP}$ at $15 \%$ of dietary DM. The increasing amount of $\mathrm{BP}$ in the diet was at the expense of decreasing an equal proportion of grain (barley or corn). All diets were high in concentrates (65\% of diet DM) and formulated to have similar concentrations of energy and protein. The portion of feedstuffs that is potentially able to be consumed by humans is known as human edible. Accordingly, human-edible protein (HEP) and human-edible energy (HEE) inputs were calculated according to the recommended potential human-edible fraction of each dietary ingredient, and HEP and HEE outputs were determined as the amount of gross energy and true protein in the milk. Feed conversion efficiency (FCE) for HEP and HEE were expressed as output per input of each variable, whereas FCE for the production of fat-corrected milk (FCM) and energy-corrected milk (ECM) were expressed as the amount of each variable
\end{abstract}

Received February 2, 2020.

Accepted May 16, 2020.

*Corresponding author: smnasrolahi@gmail.com per DM intake. Results showed that substituting BP for grain did not affect DM intake, crude protein intake, or nutrient digestibility, whereas starch intake (5.70 vs. $7.43 \mathrm{~kg} / \mathrm{d}$ for the low-BP vs. high-BP diets, respectively), HEP (2.34 and $1.92 \mathrm{~kg} / \mathrm{d}$ ), and HEE (186 and 147 MJ of gross energy/d) decreased. Treatments did not affect sorting and chewing activities, but increasing $\mathrm{BP}$ in the diet increased ruminal $\mathrm{pH}$ at $4 \mathrm{~h}$ after feeding (6.20 vs. 6.39$)$ and milk fat content (2.92 vs. $3.15 \%$ ). Similarly, FCE for ECM production (1.44 vs. 1.54) as well as FCE for HEE (0.653 vs. 0.851) and HEP (0.629 vs. 0.702$)$ were greater in high-BP diets compared with low-BP diets. The interaction of BP and grain sources significantly affected FCE for ECM production, where improvements were more evident when $\mathrm{BP}$ was substituted for barley than for corn. The improvement in FCE for HEE was greater when BP was substituted for barley (0.236) rather than corn (0.161). In conclusion, the substitution of BP for barley or corn grains in highconcentrate diets of high-producing cows decreased starch intake, increased ruminal $\mathrm{pH}$ at $4 \mathrm{~h}$ after feeding, and improved FCE for FCM production. Substitution for barley, rather than for corn, promoted greater FCE for ECM production and HEE.

Key words: beet pulp, barley, corn, dairy cow

\section{INTRODUCTION}

On some commercial dairy farms where the quality of dietary forage is moderate or low, diets may be balanced for energy requirements of high-producing cows by including high amounts of concentrate. A recent study on Iranian dairy farms reported an average concentrate inclusion of $65 \%$ of dietary DM (Esmaeili et al., 2016). This condition may increase the risk of subacute ruminal acidosis through intolerable amounts of starch degradation in the rumen, which may impair animal production and health (Zebeli et al., 2012). Additionally, a high-concentrate diet with inadequate 
NDF from forage increases the passage of undigested starch into the small intestine, where it may increasingly remain undigested or promote hindgut fermentation (Mills et al., 1999b; Reynolds, 2006; Fredin et al., 2015). All of these consequences may interfere with the efficiency of milk production and income over feed cost for dairy farms. Moreover, because starch and grains are direct ingredients of human food, consumption of grains by dairy cows may counter sustainability efforts and adversely affect the cost and availability of grains (Cassidy et al., 2013; Ertl et al., 2015b). Therefore, strategies for decreasing starch content of dairy cow diets without compromising intake and energy content are warranted and have been the subject of recently published studies (Ertl et al., 2015a; Münnich et al., 2018; Pang et al., 2018).

Beet pulp (BP) is commonly produced as a byproduct of beet-related industries and contains highly digestible NDF (40.6\% of DM; Naderi, 2014) and pectins (23\% of DM; NRC, 2001), which culminate in total DM digestibility similar to some cereal grains (Mansfield et al., 1994). Pectin digestion in the rumen produces less lactate and propionate than does starch fermentation and does not interfere with cellulose and hemicellulose digestion (Hall and Herejk, 2001). Additionally, a high cation exchange capacity (McBurney et al., 1983) and $\mathrm{K}$ content (NRC, 2001) of BP can buffer against organic acids produced during ruminal fermentation (Marounek et al., 1985). The substitution of BP for cereal grains has been shown to be effective for decreasing dietary starch content and improving ruminal health (Voelker and Allen, 2003b; Mahjoubi et al., 2009) without adverse effects on milk production (Voelker and Allen, 2003a; Alamouti et al., 2009; Mahjoubi et al., 2009). Moreover, because BP is not an edible human food ingredient, its dietary inclusion decreases the humanedible (HE) portion of a dairy cow diet and increases the efficiency of converting HE ingredients to milk (Ertl et al., 2015b; Münnich et al., 2018).

Despite various research on the substitution of $\mathrm{BP}$ for grains, to our knowledge, the effect of substituted grain type has not been evaluated. Barley and corn grains are 2 major starch sources that are fed to dairy cows (Kargar et al., 2014). Starch in barley grain is characterized by a high ruminal degradation rate, so a high level of inclusion in the diet can cause ruminal acidosis and inflammatory responses (Emmanuel et al., 2008). Starch in corn grain has a slower ruminal degradation rate than that of barley, which may help to alleviate ruminal acidosis, but at a high level of feeding in high-concentrate diets, this lower degradation rate can increase the passage of undigested starch into the small intestine, where it may increasingly remain undigested or promote hindgut fermentation (Mills et al., 1999b;
Reynolds, 2006). We hypothesized that the substitution of BP for barley or corn could produce different results on the metabolism and productive performance of dairy cows fed high-concentrate diets. Therefore, the objective of this study was to test the effects of partial substitution of BP for barley or corn grain in dairy cow diets on feeding behavior, productive performance, and ruminal fermentation.

\section{MATERIALS AND METHODS}

\section{Cows, Diets, and Treatments}

The experiment was conducted from November 2015 to February 2016 at the FKA Agriculture and Animal Husbandry Unit (Isfahan, Iran). All animal procedures were approved by the Animal Care Committee of Isfahan University of Technology (Isfahan, Iran), according to the Iranian Council of Animal Care (1995), with approval number IRN-0002-5-16. Eight second-parity Holstein cows $(62 \pm 2$ DIM; milk yield $=54 \pm 1.2 \mathrm{~kg} / \mathrm{d}$; $\mathrm{BW}=624 \pm 26 \mathrm{~kg}$ ) were used in a replicated $4 \times 4$ Latin square design with 4 periods of $21 \mathrm{~d}$ ( $15 \mathrm{~d}$ for diet adaptation and $6 \mathrm{~d}$ for sampling and data collection). Cows were randomly assigned to 1 of 4 treatments that were arranged as a $2 \times 2$ factorial of 2 grain sources (corn or barley grain) and 2 levels of BP inclusion (5 or $15 \%$ of DM) in the diet. Treatments were (1) barley-based diet with $\mathrm{BP}$ at $5 \%$ of dietary DM; (2) barley-based diet with BP at $15 \%$ of dietary DM; (3) corn-based diet with BP at $5 \%$ of dietary DM; and (4) corn-based diet with BP at $15 \%$ of dietary DM. In all cases, BP in the diet was substituted directly for an equal amount of grain (barley or corn) on a DM basis, and the diets were formulated to have similar concentrations of energy and protein. Diets were formulated using the Cornell Net Carbohydrate and Protein System (version 5.0 ; Fox et al., 2000) for cows producing $45 \mathrm{~kg} / \mathrm{d}$ of milk with $3.2 \%$ fat and $3.0 \%$ CP. Ingredients and chemical composition of the diets are shown in Table 1 . The ratio of forage to concentrates in all diets was $35 \%$ to $65 \%$ on a DM basis. Barley and corn grains were ground using a hammer mill with a sieve size of $3 \mathrm{~mm}$ (model 5543 GEN; Isfahan Dasht, Isfahan, Iran). During the experiment, cows were housed in individual $6-\mathrm{m} \times 4-\mathrm{m}$ pens bedded with sand, with free access to water. Cows were fed $110 \%$ of actual feed intake of the previous day and were fed twice daily at 0900 and $1630 \mathrm{~h}$.

\section{Feed Intake, Nutrient Digestibility, and Chemical Analysis}

The TMR amounts delivered and refused were weighed and sampled daily for each cow during d 16 
Table 1. Ingredients and chemical composition of the experimental $\operatorname{diets}^{1}$

\begin{tabular}{|c|c|c|c|c|}
\hline \multirow[b]{2}{*}{ Item } & \multicolumn{2}{|c|}{ Barley grain } & \multicolumn{2}{|c|}{ Corn grain } \\
\hline & $5 \% \mathrm{BP}$ & $15 \% \mathrm{BP}$ & $5 \% \mathrm{BP}$ & $15 \% \mathrm{BP}$ \\
\hline \multicolumn{5}{|l|}{ Ingredient composition, $\%$ of DM } \\
\hline Alfalfa hay & 17.5 & 17.5 & 17.5 & 17.5 \\
\hline Corn silage & 17.5 & 17.5 & 17.5 & 17.5 \\
\hline Beet pulp & 5 & 15 & 5 & 15 \\
\hline Ground barley grain & 35.7 & 25.7 & 0 & 0 \\
\hline Ground corn grain & 0 & 0 & 35 & 25 \\
\hline Soybean meal & 12.1 & 12.1 & 13.6 & 13.5 \\
\hline Cottonseed & 4 & 4 & 4 & 4 \\
\hline Meat meal & 2.5 & 2.5 & 2.5 & 2.5 \\
\hline Fat powder ${ }^{2}$ & 2.7 & 2.7 & 1.9 & 2.0 \\
\hline Sodium bicarbonate & 1 & 1 & 1 & 1 \\
\hline Salt & 0.33 & 0.33 & 0.33 & 0.33 \\
\hline Mineral premix ${ }^{3}$ & 0.33 & 0.33 & 0.33 & 0.33 \\
\hline Vitamin premix ${ }^{4}$ & 0.33 & 0.33 & 0.33 & 0.33 \\
\hline Calcium carbonate & 1 & 1 & 1 & 1 \\
\hline \multicolumn{5}{|c|}{ Chemical composition, \% of DM otherwise stated } \\
\hline DM, $\%$ as fed & 46.8 & 47.0 & 46.4 & 46.7 \\
\hline $\mathrm{OM}$ & 89.7 & 90.6 & 90.0 & 90.7 \\
\hline $\mathrm{NDF}$ & 32.2 & 34.7 & 28.3 & 31.9 \\
\hline NDF from forage, $\%$ of NDF & 19.8 & 19.8 & 19.8 & 19.8 \\
\hline Forage NDF/total NDF & 0.615 & 0.571 & 0.699 & 0.621 \\
\hline $\mathrm{ADF}$ & 19.6 & 21.2 & 18.4 & 20.3 \\
\hline $\mathrm{CP}$ & 16.5 & 16.4 & 16.5 & 16.5 \\
\hline Ether extract & 5.6 & 5.6 & 5.6 & 5.3 \\
\hline $\mathrm{NFC}^{5}$ & 39.8 & 37.5 & 43.8 & 40.4 \\
\hline Starch & 24.7 & 19.5 & 29.6 & 22.9 \\
\hline $\mathrm{NE}_{\mathrm{L}},{ }^{6} \mathrm{MJ} / \mathrm{kg}$ of $\mathrm{DM}$ & 6.90 & 6.86 & 6.90 & 6.86 \\
\hline
\end{tabular}

${ }^{1}$ Experimental diets were a barley-based diet with sugar beet pulp (BP) at $5 \%$ of dietary DM; a barley-based diet with $\mathrm{BP}$ at $15 \%$ of dietary DM; a corn-based diet with $\mathrm{BP}$ at $5 \%$ of dietary DM; and a corn-based diet with $\mathrm{BP}$ at $15 \%$ of dietary DM.

${ }^{2}$ Fat powder C16:0-enriched palm fat contained $99.5 \%$ total, $73.5 \% \mathrm{C} 16: 0,5 \% \mathrm{C} 18: 0,10 \% \mathrm{C} 18: 1$, and $0.3 \%$ C18:2, respectively.

${ }^{3}$ Mineral premix contained $0.5 \% \mathrm{Ca}, 1.60 \% \mathrm{Zn}, 0.012 \% \mathrm{Co}, 0.40 \% \mathrm{Cu}, 0.015 \% \mathrm{I}, 0.08 \% \mathrm{Fe}, 1.00 \% \mathrm{Mn}, 0.008 \%$ Se, and $0.125 \%$ butylated hydroxytoluene as a synthetic antioxidant.

${ }^{4}$ Vitamin premix contained $1,300,000 \mathrm{IU} / \mathrm{kg}$ of vitamin $\mathrm{A}, 360,000 \mathrm{IU} / \mathrm{kg}$ of vitamin $\mathrm{D}$, and $15,000 \mathrm{IU} / \mathrm{kg}$ of vitamin E.

${ }^{5}$ Nonfibrous carbohydrate $=100-(\mathrm{CP}+\mathrm{NDF}+$ ether extract + ash $)(\mathrm{NRC}, 2001)$.

${ }^{6}$ Calculated according to NRC (2001).

to 21 of each period, and daily DMI for each cow was calculated. Representative samples of treatment TMR (pooled by diet within period) and individual refusals (pooled by cow within period) were taken immediately before the morning feeding during the 6 - $\mathrm{d}$ collection period. All samples were immediately frozen at $-20^{\circ} \mathrm{C}$ until analysis. After thawing, the DM concentration of samples was determined by drying at $60^{\circ} \mathrm{C}$ in a forcedair oven for $48 \mathrm{~h}$ (Townshend, 1995). All samples were ground using a Wiley mill with a 1-mm screen (Arthur H. Thomas, Philadelphia, PA) and were analyzed for CP (AOAC International, 2006; method 955.04), ether extract (AOAC International, 2006; method 920.39), ash (AOAC International, 2006; method 942.05), NDF using heat-stable $\alpha$-amylase and sodium sulfite, and ADF (Van Soest et al., 1991). Nonfiber carbohydrate content, in percent, was calculated as $100-(\mathrm{CP}+$
NDF + ether extract + ash), according to NRC (2001). The starch concentration in feed and fecal samples was determined using the modified glucoamylase procedure described by Zhu et al. (2016). Briefly, samples were gelatinized by boiling in a water bath for 20 min and then cooled to ambient temperature. After the addition of acetate buffer, starch was hydrolyzed with a glucoamylase enzyme, and glucose concentration was measured using the glucose oxidase method (Pars Azmoon Co., Tehran, Iran). Net energy for lactation was calculated according to a standard equation (NRC, 2001).

Fecal grab samples were obtained from each cow for 4 consecutive days at 12-h intervals (Cooke et al., 2008). Sampling time was advanced by $2 \mathrm{~h}$ each day, so that samples were collected at 0500, 0700, 0900, 1100, 1700, 1900, 2100, and $2300 \mathrm{~h}$. The samples were composited by cow and kept frozen at $-20^{\circ} \mathrm{C}$ until analysis. Af- 
ter thawing, fecal samples were dried in a forced-air oven at $60^{\circ} \mathrm{C}$ for $72 \mathrm{~h}$, ground to pass through a $1-\mathrm{mm}$ screen, and analyzed for DM, ash, ADF, NDF, starch, and $\mathrm{CP}$ by procedures previously described. Apparent total-tract digestibility of nutrients was determined using undigested NDF after $288 \mathrm{~h}$ of in situ ruminal incubation as an internal marker using 2 ruminally cannulated nonlactating Holstein dairy cows (Bender et al., 2016; Kahyani et al., 2019).

\section{Particle Size Measurement, Sorting Behavior, and Chewing Activity}

During d 16 to 19 of the study, TMR and orts were collected daily for determination of particle size. Particle size was measured in triplicate using the Penn State Particle Separator, equipped with 3 sieves and a bottom pan (Kononoff et al., 2003). After sieving, samples were placed in a forced-air oven at $60^{\circ} \mathrm{C}$ to determine the DM of each sieved fraction. The physically effective factor (pef) values were determined as the total proportion of DM retained on 2 sieves (pef8; Lammers et al., 1996) or 3 sieves of the Penn State Particle Separator (pef1.18; Kononoff et al., 2003; Table 2 ), respectively. The physically effective NDF of 2 and 3 sieves (peNDF8 and peNDF1.18, respectively) were calculated by multiplying pef 8 and pef1.18 by the NDF content of the diet (DM basis), respectively. The geometric mean particle size of TMR and orts was calculated according to ASAE (1995) procedures. Sorting of particles was determined from the actual intake of each fraction compared with the predicted intake of the same fraction had the diet been consumed as formulated (Leonardi and Armentano, 2003).
On d 20 of each period, chewing activity was monitored visually for each cow for $24 \mathrm{~h}$. Three people participated in the observation, where a single observer monitored cows constantly for $4 \mathrm{~h}$ and then was replaced by a new observer. During the 24 -h period, eating and ruminating activities were recorded every 5 min, where the observer required approximately $1 \mathrm{~min}$ to make observations for all cows, and the activity of each cow was assumed to persist for the entire 5-min interval between observations (Beauchemin et al., 2003). The total chewing time was calculated as the sum of ruminating and eating time.

\section{Ruminal Fermentation}

On d 21 of each period, approximately $4 \mathrm{~h}$ after the morning feeding, ruminal fluid (approximately $3 \mathrm{~mL}$ ) was sampled from the ventral sac via rumenocentesis (Nordlund and Garrett, 1994) as implemented by Nasrollahi et al. (2017). The $\mathrm{pH}$ of the ruminal fluid was immediately determined using a portable digital pH meter (HI 8318; Hanna Instruments, Cluj-Napoca, Romania) calibrated at $\mathrm{pH} 4$ and 7 at the start of each measuring day. Then, $2 \mathrm{~mL}$ of the collected sample was acidified with $0.4 \mathrm{~mL}$ of a $25 \%$ meta-phosphoric acid solution and frozen immediately at $-20^{\circ} \mathrm{C}$ until subsequent analysis for VFA. Ruminal fluid for VFA determination was subsequently thawed and centrifuged at $10,000 \times g$ at $4^{\circ} \mathrm{C}$ for $20 \mathrm{~min}$ and analyzed via gas chromatography (Chrompack, model CP-9002; Chrompack International BV, Middelburg, the Netherlands) as described by Hashemzadeh-Cigari et al. (2014). Ruminal $\mathrm{NH}_{3}-\mathrm{N}$ concentration was measured according to the procedure described by Broderick and Kang (1980).

Table 2. Physical characteristics of experimental diets measured using the Penn State Particle Separator ${ }^{1}$

\begin{tabular}{|c|c|c|c|c|}
\hline \multirow[b]{2}{*}{ Item } & \multicolumn{2}{|c|}{ Barley } & \multicolumn{2}{|c|}{ Corn } \\
\hline & $5 \% \mathrm{BP}$ & $15 \% \mathrm{BP}$ & $5 \% \mathrm{BP}$ & $15 \% \mathrm{BP}$ \\
\hline \multicolumn{5}{|l|}{ DM retained on sieve, $\%$} \\
\hline $19.0 \mathrm{~mm}$ & 9.40 & 10.5 & 10.3 & 10.4 \\
\hline $8.0 \mathrm{~mm}$ & 25.0 & 27.3 & 25.6 & 26.5 \\
\hline $1.18 \mathrm{~mm}$ & 41.4 & 43.1 & 39.6 & 42.4 \\
\hline Pan & 24.1 & 19.0 & 24.4 & 20.5 \\
\hline peNDF $>8.0 .^{2} \%$ of DM & 11.0 & 13.1 & 10.1 & 11.8 \\
\hline peNDF $>1.18,{ }^{2} \%$ of DM & 24.4 & 28.1 & 21.3 & 25.3 \\
\hline GMPS, ${ }^{3} \mathrm{~mm}$ & 4.23 & 4.8 & 4.32 & 4.65 \\
\hline
\end{tabular}

${ }^{1}$ Experimental diets were a barley-based diet with sugar beet pulp (BP) at $5 \%$ of dietary DM; a barley-based diet with $\mathrm{BP}$ at $15 \%$ of dietary DM; a corn-based diet with $\mathrm{BP}$ at $5 \%$ of dietary DM; and a corn-based diet with $\mathrm{BP}$ at $15 \%$ of dietary DM.

${ }^{2}$ Particle length variables were measured using the Penn State Particle Separator (The Pennsylvania State University, University Park, PA; Kononoff et al., 2003). pef $>8$ and pef $>1.18=$ physical effectiveness factor, determined as the proportion of particles retained on 2 sieves (Lammers et al., 1996) and on 3 sieves (Kononoff et al., 2003), respectively; peNDF $>8$ and peNDF $>1.18$ = physically effective NDF determined as NDF content of TMR multiplied by pef $>8$ and pef $>1.18$, respectively.

${ }^{3}$ GMPS $=$ geometric mean particle size. 


\section{Milk Yield and Components}

Milk yield for all cows was recorded and sampled at each milking during d 16 to 21 of each period. Cows were milked 3 times daily at 0800,1600 , and $2400 \mathrm{~h}$, in a herringbone milking parlor. Milk samples were preserved with potassium dichromate, stored at $4^{\circ} \mathrm{C}$, and submitted to the Isfahan University of Technology's Central Milk Testing Laboratory (Isfahan, Iran) for fat, protein, and lactose analyses, using an infrared analyzer (MilkoScan 134 BN; Foss Electric, Hillerød, Denmark; AOAC International, 2006; method 972.16). The MUN content was determined via enzymatic assay (Wilson et al., 1998). The yield of 4\% FCM (kg/d) and ECM $(\mathrm{kg} / \mathrm{d})$ was calculated using the following equations $(\mathrm{NRC}, 2001): \mathrm{FCM}(\mathrm{kg} / \mathrm{d})=0.4 \times$ milk yield $(\mathrm{kg} / \mathrm{d})+15 \times$ milk fat yield $(\mathrm{kg} / \mathrm{d}) ; \mathrm{ECM}(\mathrm{kg} / \mathrm{d})=$ $0.323 \times$ milk yield $(\mathrm{kg} / \mathrm{d})+12.82 \times$ milk fat yield $(\mathrm{kg} / \mathrm{d})+7.13 \times$ milk protein yield $(\mathrm{kg} / \mathrm{d})$. Feed conversion efficiency (FCE) for the production of milk, FCM, and ECM were calculated as the amount of each variable per DM intake on a kilogram per kilogram basis.

\section{Calculation and Statistical Analysis}

The portion of feedstuffs able to be consumed by humans is known as human edible. Accordingly, the human-edible protein (HEP) and human-edible energy (HEE) inputs were calculated according to the human-edible fraction of each ingredient (Wilkinson, 2011). The HEP and HEE outputs consisted of total gross energy and true protein in the milk, respectively. The FCE for HEP and HEE were calculated as HEP output per HEP input and as HEE output per HEE input, respectively.

Data were analyzed using the mixed model procedure of SAS (Proc Mixed; SAS, 2002) to account for the effects of square, cow within square, period, and treatment (grain source, BP level, and their interaction). The treatment, square, and period were considered as fixed effects, whereas cow within square was a random effect. The mixed model used for data analysis was as follows:

$$
\begin{aligned}
\mathrm{Y}_{\mathrm{ijklm}}=\mu & +\mathrm{S}_{\mathrm{m}}+\mathrm{P}_{\mathrm{i}}+\mathrm{A}(\mathrm{S})_{\mathrm{jm}}+\mathrm{R}_{\mathrm{k}}+\mathrm{D}_{\mathrm{l}} \\
& +(\mathrm{R} \times \mathrm{D})_{\mathrm{kl}}+\mathrm{e}_{\mathrm{ijklm}},
\end{aligned}
$$

where $Y_{\mathrm{ijklm}}=$ each observation, $\mu=$ overall mean, $\mathrm{S}_{\mathrm{m}}$ = fixed effect of square, $\mathrm{P}_{\mathrm{i}}=$ fixed effect of period, $\mathrm{A}(\mathrm{S})_{\mathrm{jm}}=$ random effect of cow within square, $R_{\mathrm{k}}=$ fixed effect of grain source, $\mathrm{D}_{1}=$ fixed effect of $\mathrm{BP}$ inclusion rate, $(\mathrm{R} \times \mathrm{D})_{\mathrm{kl}}=$ interaction between $\mathrm{R}_{\mathrm{k}}$ and $D_{1}$, and $\mathrm{e}_{\mathrm{ijklm}}=$ random residual error.
Data were reported as least squares means. Statistical significance was considered when $P \leq 0.05$, whereas a statistical tendency was considered when $0.05<P \leq$ 0.10 .

\section{RESULTS}

\section{Diet Characteristics and Particle Size Distribution}

Ingredients, chemical composition, and particle size distributions of experimental diets are shown in Tables 1 and 2 on a DM basis. The starch content (27.2 vs. $21.2 \%$ of $\mathrm{DM}$ for the low-BP vs. high-BP diets, respectively), HEE (1.63 vs. 1.31 Mcal of gross energy/ $\mathrm{kg}$ of $\mathrm{DM}$ ), and HEP (7.91 vs. $7.16 \%$ of DM) were greater in the low-BP diets than in the high-BP diets, whereas NDF content was lower in the low-BP diets (30.3 vs. $33.3 \%$ of DM). Although the proportion of particles retained on the top $(19 \mathrm{~mm})$ and second sieves (8-19 mm) of the Penn State Particle Separator did not differ among treatments, the proportion of particles retained on the third sieve $(1.18-8 \mathrm{~mm})$ was lower for the low-BP diets than for the high-BP diets (40.5 vs. $42.8 \%$ of $\mathrm{DM}$ ), whereas particles retained on the bottom pan were greater for the low-BP diets than for the high-BP diets (24.3 vs. $19.8 \%$ of DM). As a result, peNDF8.0 (10.6 vs. $12.5 \%$ of DM), peNDF1.18 (22.9 and $26.7 \%$ of DM), and geometric mean particle size were lower in low-BP than in high-BP diets. The value for peNDF1.18 (26.3 vs. $23.3 \%$ of DM for barley-based vs. corn-based diets, respectively) was also greater in barley-based diets than in corn-based diets.

\section{Nutrient Intake and Digestibility}

No interaction was detected between the effects of grain sources and BP inclusion levels on nutrient intake and digestibility (Table 3). Substituting BP for grains increased NDF intake $(P<0.05)$ but decreased starch, HEE, and HEP intakes of cows $(P<0.01)$. Cows fed corn-based diets had greater intake of DM, OM, CP, and starch but lower intake of NDF, HEE, and HEP compared with those fed barley-based diets $(P<0.05)$. Grain source and BP level did not affect total-tract digestibility of DM, OM, CP, and starch, whereas NDF digestibility increased $(P=0.05)$ and ADF digestibility tended to increase $(P=0.09)$ when cows were fed with corn rather than barley grain.

\section{Sorting and Chewing}

Generally, grain source, BP inclusion levels, and the interaction thereof did not affect sorting or chewing behaviors (Table 4). Cows fed diets containing corn grain 
Table 3. Nutrient intake and apparent total-tract nutrient digestibility as influenced by substituting sugar beet pulp for grain sources (barley or corn $)^{1}$

\begin{tabular}{|c|c|c|c|c|c|c|c|c|}
\hline \multirow[b]{2}{*}{ Item } & \multicolumn{2}{|c|}{ Barley } & \multicolumn{2}{|c|}{ Corn } & \multirow[b]{2}{*}{ SEM } & \multicolumn{3}{|c|}{$P$-value ${ }^{2}$} \\
\hline & $5 \% \mathrm{BP}$ & $15 \% \mathrm{BP}$ & $5 \% \mathrm{BP}$ & $15 \% \mathrm{BP}$ & & Grain & $\mathrm{BP}$ & Grain $\times \mathrm{BP}$ \\
\hline DM & 26.6 & 26.0 & 28.0 & 27.6 & 0.76 & 0.01 & 0.37 & 0.87 \\
\hline $\mathrm{OM}$ & 23.6 & 23.4 & 24.7 & 24.6 & 0.67 & 0.02 & 0.76 & 0.97 \\
\hline $\mathrm{CP}$ & 4.37 & 4.34 & 4.59 & 4.53 & 0.127 & 0.04 & 0.6 & 0.87 \\
\hline $\mathrm{NDF}$ & 8.68 & 8.96 & 7.85 & 8.83 & 0.298 & 0.03 & 0.006 & 0.09 \\
\hline $\mathrm{HEP}^{3}$ & 2.06 & 1.82 & 2.63 & 2.02 & 0.058 & $<0.01$ & $<0.01$ & 0.96 \\
\hline $\mathrm{HEE},{ }^{3} \mathrm{MJ}$ of gross energy/d & 167 & 132 & 206 & 162 & 4.85 & $<0.01$ & $<0.01$ & 0.19 \\
\hline \multicolumn{9}{|l|}{ Digestibility, $\%$ of DM } \\
\hline DM & 70.5 & 68.3 & 68.9 & 68.6 & 1.13 & 0.53 & 0.22 & 0.36 \\
\hline $\mathrm{OM}$ & 72.9 & 71.2 & 69.8 & 70.7 & 1.25 & 0.13 & 0.69 & 0.27 \\
\hline $\mathrm{CP}$ & 72.3 & 72.3 & 70.1 & 69.4 & 2.07 & 0.12 & 0.85 & 0.86 \\
\hline $\mathrm{NDF}$ & 48.1 & 51.7 & 54.6 & 53.0 & 1.91 & 0.05 & 0.61 & 0.18 \\
\hline
\end{tabular}

${ }^{1}$ Experimental diets were a barley-based diet with sugar beet pulp (BP) at $5 \%$ of dietary DM; a barley-based diet with BP at $15 \%$ of dietary $\mathrm{DM}$; a corn-based diet with $\mathrm{BP}$ at $5 \%$ of dietary DM; and a corn-based diet with $\mathrm{BP}$ at $15 \%$ of dietary DM.

${ }^{2}$ Grain $=$ effect of grain sources; $\mathrm{BP}=$ effect of beet pulp level; Grain $\times \mathrm{BP}=$ interaction of grain sources and beet pulp level.

${ }^{3}$ Human-edible protein (HEP) and human-edible energy (HEE) were calculated according to recommendations by Wilkinson (2011).

spent more time chewing per day $(P<0.05)$, but when chewing was expressed per kilogram of DMI, this effect was not significant.

\section{Ruminal Fermentation}

Substituting BP for grains increased ruminal $\mathrm{pH}$ (6.20 vs. $6.38 ; P<0.05$; Table 5). Substituting BP for barley was accompanied with a higher molar propor- tion of acetate in ruminal fluid, but the effect was not significant for $\mathrm{BP}$ substitution of corn $(\mathrm{BP} \times$ grain; $P$ $=0.05)$. In cows fed barley-based diets, compared with corn-based diets, the molar proportion of propionate was higher $(26.9$ vs. $24.8 \% ; P<0.05)$, but butyrate was lower $(10.9$ vs. $12.6 \%$; $P<0.05)$. Total VFA concentration in ruminal fluid, acetate-to-propionate ratio, and molar proportions of isobutyrate, valerate, and isovalerate were not affected by treatments.

Table 4. Sorting index and feeding behavior as influenced by substituting sugar beet pulp for grain sources (barley or corn) ${ }^{1}$

\begin{tabular}{|c|c|c|c|c|c|c|c|c|}
\hline Item & \multicolumn{2}{|c|}{ Barley } & \multicolumn{2}{|c|}{ Corn } & SEM & \multicolumn{3}{|c|}{$P$-value ${ }^{2}$} \\
\hline \multicolumn{9}{|l|}{ Sorting index ${ }^{3}$} \\
\hline $8.0 \mathrm{~mm}$ & 98.7 & 96.8 & 97.5 & 98.3 & 1.10 & 0.92 & 0.61 & 0.23 \\
\hline $1.18 \mathrm{~mm}$ & 100.4 & 101.8 & 101.4 & 100.8 & 0.98 & 0.97 & 0.66 & 0.32 \\
\hline Pan & 99.2 & 101.9 & 100.7 & 101.4 & 1.29 & 0.75 & 0.20 & 0.45 \\
\hline $\min / \mathrm{kg}$ of DMI & 14.8 & 15.8 & 15.1 & 15.4 & 0.61 & 0.84 & 0.24 & 0.55 \\
\hline \multicolumn{9}{|l|}{ Eating time } \\
\hline $\min / \mathrm{d}$ & 282 & 294 & 292 & 298 & 11.56 & 0.36 & 0.63 & 0.59 \\
\hline $\mathrm{min} / \mathrm{kg}$ of DMI & 10.7 & 11.3 & 10.8 & 10.9 & 0.67 & 0.73 & 0.45 & 0.64 \\
\hline \multicolumn{9}{|l|}{ Total chewing time } \\
\hline $\min / \mathrm{d}$ & 677 & 705 & 718 & 723 & 13.86 & 0.04 & 0.24 & 0.42 \\
\hline $\mathrm{min} / \mathrm{kg}$ of $\mathrm{DMI}$ & 25.6 & 27.2 & 25.9 & 26.3 & 0.91 & 0.72 & 0.19 & 0.47 \\
\hline
\end{tabular}

${ }^{1}$ Experimental diets were a barley-based diet with sugar beet pulp (BP) at $5 \%$ of dietary DM; a barley-based diet with BP at $15 \%$ of dietary DM; a corn-based diet with $\mathrm{BP}$ at $5 \%$ of dietary DM; and a corn-based diet with BP at $15 \%$ of dietary DM.

${ }^{2}$ Grain $=$ effect of grain sources; $\mathrm{BP}=$ effect of beet pulp level; Grain $\times \mathrm{BP}=$ interaction of grain sources and beet pulp level.

${ }^{3}$ The sorting index was calculated as the ratio of actual intake to expected intake for particles retained on each sieve of the Penn State Particle Separator (Leonardi and Armentano, 2003). Values equal to 100 indicate no sorting, values $<100$ indicate sorting against, and values $>100$ indicate sorting for. 


\section{Milk Production and Composition}

Milk production and composition data are presented in Table 6. Substituting BP for grains increased the content of milk fat and fat-to-protein ratio $(P \leq 0.05)$ and tended to increase the production of milk fat $(P$ $=0.07)$. The interaction of grain source and BP level tended to affect the production of FCM, ECM, and fat $(P<0.09)$, and these measures were greater when $\mathrm{BP}$ was substituted for barley rather than for corn. The FCE for FCM production increased as BP level increased in the diet $(1.45$ vs. $1.55 ; P<0.05)$. The FCE for ECM production increased with increased BP level only when substituted for barley grain $(\mathrm{BP} \times$ grain; $P=0.05)$. Also, the FCE for HEP and HEE outputs increased as beet pulp level increased $(P<0.01)$, but when BP was substituted for barley, the improvement for HEE was greater than when BP was substituted for corn $(\mathrm{BP} \times$ grain; $P<0.01)$. Feeding corn grain compared with barley grain improved milk, FCM, ECM, protein, and lactose production as well as the content of lactose in milk, but the content of other components and the FCE for milk production were not affected by grain source. The FCE for HEP output was decreased by feeding corn rather than barley. The concentration of MUN was not affected by the treatments and on average was $15.4 \mathrm{mg} / \mathrm{dL}$.

\section{DISCUSSION}

The high-concentrate and high-starch diets that are commonly fed to high-producing dairy cows have been the subject of several research studies on adverse outcomes such as poor economic efficiency, decreased sustainability, and impaired animal welfare (Reyn- olds, 2006; Zebeli et al., 2012; Cassidy et al., 2013). Substituting a non-forage fiber source such as BP for grain has been shown to be an economical, healthy, and sustainable strategy because it improves ruminal $\mathrm{pH}$ and decreases starch and $\mathrm{HE}$ inclusions in diets while maintaining production performance (Ertl et al., 2015b; Pang et al., 2018). In the present study, however, we demonstrate that BP substitution for grains has different effects that depend on grain source (barley or corn). Barley and corn grains differ in the amount, rate, and site of starch digestion, which may explain the outcomes of the present study (Mills et al., 1999a; Reynolds, 2006; Albornoz and Allen, 2018).

Substitution of BP for both barley and corn grains decreased starch intake, HEP intake, and HEE intake, but increased NDF intake by cows. Because the treatments did not affect sorting, the effects on actual intake are related directly to diet formulation. The decreased starch and increased NDF intake of the present study did affect DM digestibility, and this finding agrees with previous in vivo (Münnich et al., 2018) and in vitro (Ertl et al., 2015a) studies. Indeed, the high digestibility of fiber and pectin in diets with greater BP inclusion resulted in total-tract digestibly of DM comparable to that of diets formulated with greater inclusion of cereal grains. Moreover, the decrease in ruminal $\mathrm{pH}$ that is reported in previous research (Mahjoubi et al., 2009; Ertl et al., 2015a) of diets containing increased grain inclusions (low level of BP) can potentially decrease nutrient digestibility (Grant and Mertens, 1992; Calsamiglia et al., 2002; Fernando et al., 2010). In the present study, intake of cows fed barley-based diets was lower than that of cows fed corn-based diets, and this finding agrees with previous studies that reported lower feed intake for cows fed barley rather than corn

Table 5. Ruminal fermentation characteristics and fecal $\mathrm{pH}$ as influenced by substituting sugar beet pulp for grain sources (barley or corn) ${ }^{1}$

\begin{tabular}{|c|c|c|c|c|c|c|c|c|}
\hline Item & \multicolumn{2}{|c|}{ Barley } & \multicolumn{2}{|c|}{ Corn } & SEM & \multicolumn{3}{|c|}{$P$-value ${ }^{2}$} \\
\hline Ruminal pH & 6.28 & 6.31 & 6.13 & 6.46 & 0.148 & 0.80 & 0.03 & 0.66 \\
\hline Total VFA, mmol/L & 109.3 & 115.1 & 113.0 & 111.7 & 2.19 & 0.93 & 0.3 & 0.11 \\
\hline VFA proportions, $\mathrm{mol} / 100 \mathrm{~mol}$ & & & & & & & & \\
\hline Acetate $(\mathrm{A})$ & $56.5^{\mathrm{b}}$ & $60.8^{\mathrm{a}}$ & 58.9 & 59.1 & 0.99 & 0.76 & 0.03 & 0.05 \\
\hline Valerate & 1.01 & 0.93 & 1.13 & 1.01 & 0.062 & 0.13 & 0.12 & 0.78 \\
\hline Isovalerate & 1.14 & 1.07 & 1.12 & 1.10 & 0.050 & 0.99 & 0.32 & 0.60 \\
\hline $\mathrm{A}: \mathrm{P}$ & 2.04 & 2.39 & 2.41 & 2.42 & 0.131 & 0.14 & 0.19 & 0.19 \\
\hline Fecal pH & 6.82 & 6.55 & 6.54 & 6.57 & 0.092 & 0.17 & 0.21 & 0.11 \\
\hline
\end{tabular}

${ }^{\mathrm{a}, \mathrm{b}}$ Within grain, means of BP levels with different superscripts differ $(P \leq 0.05)$.

${ }^{1}$ Experimental diets were a barley-based diet with sugar beet pulp (BP) at 5\% of dietary DM; a barley-based diet with BP at $15 \%$ of dietary DM; a corn-based diet with BP at $5 \%$ of dietary DM; and a corn-based diet with BP at $15 \%$ of dietary DM.

${ }^{2}$ Grain $=$ effect of grain sources; $\mathrm{BP}=$ effect of beet pulp level; Grain $\times \mathrm{BP}=$ interaction of grain sources and beet pulp level. 
(Silveira et al., 2007; Nasrollahi et al., 2012). Similarly, the present study reported a higher ruminal propionate concentration for cows fed barley rather than corn. Increased concentration of propionate in the ruminal fluid is known to decrease feed intake (Allen, 2000).

In the present study, fiber digestibility was lower in barley-based diets than in corn-based diets. This result has been documented previously and may be due to greater ruminal escape of fiber particles in barley grain than in corn grain (Nasrollahi et al., 2012). Moreover, compared with corn-based diets, barley-based diets contained a slightly greater ADF level and likely a greater lignin content, which might also negatively affect fiber quality and digestibility.

The average ruminal $\mathrm{pH}$ of cows in the present study was 6.30. This value is high and inconsistent with previous studies where high-concentrate diets were tested (Voelker and Allen, 2003b; Kahyani et al., 2019; Nasrollahi et al., 2019; Razzaghi et al., 2020). Two main differences between the present study and these referenced reports were different sorting activities of cows and supplementation of sodium bicarbonate. In the present study, no sorting against long particles was identified (i.e., particles $>19 \mathrm{~mm}$ ), and all sorting indexes were close to 100. In contrast, Nasrollahi et al. (2019) reported a low ruminal pH (5.96) for cows fed high levels of concentrate, accompanied by extensive sorting against long particles, with an average sorting index for particles $>19 \mathrm{~mm}$ of 77 [sorting data are reported by S. M. Nasrollahi, A. Zali (University of Tehran, Tehran, Iran), G. R. Ghorbani, M. Khani (Isfahan University of Technology, Isfahan, Iran), H. Maktabi (Isfahan University of Technology, Isfahan, Iran), H. Guyot (University of Liege, Liege, Belgium), and A. Kahyani (Isfahan University of Technology, Isfahan, Iran), unpublished data]. Kahyani et al. (2019) reported that cows sorting selectively against particles $>19 \mathrm{~mm}$ had lower ruminal $\mathrm{pH}$ (sorting index $=86$; ruminal $\mathrm{pH}=5.90)$ than cows that sorted less against those particles (sorting index $=99$; ruminal $\mathrm{pH}=6.28$ ). The effect of ingestion of long particles on increased ruminal $\mathrm{pH}$ may be related to increased chewing activity and improved ruminal health and function (Mertens, 1997). Using sodium bicarbonate in the present study also could have contributed to the higher ruminal $\mathrm{pH}$ that was observed, compared with previous studies that did not use sodium bicarbonate (Voelker and Allen, 2003b; Nasrollahi et al., 2019; Razzaghi et al., 2020).

It should be noted that the ruminal $\mathrm{pH}$ measurements of the present study were based on a spot sampling of ruminal $\mathrm{pH}$ via rumenocentesis $4 \mathrm{~h}$ after feeding, so $\mathrm{pH}$ changes and fluctuation throughout a 24 -h period were not characterized. However, a previous comparison of ruminal $\mathrm{pH}$ measurements produced by rumenocentesis and indwelling rumenoreticular probes produced a consistent ranking of cows based on ruminal pH (Nasrol-

Table 6. Lactation performance as influenced by substituting sugar beet pulp for grain sources (barley or corn) $)^{1}$

\begin{tabular}{|c|c|c|c|c|c|c|c|c|}
\hline \multirow[b]{2}{*}{ Item } & \multicolumn{2}{|c|}{ Barley } & \multicolumn{2}{|c|}{ Corn } & \multirow[b]{2}{*}{ SEM } & \multicolumn{3}{|c|}{$P$-value ${ }^{2}$} \\
\hline & $5 \% \mathrm{BP}$ & $15 \% \mathrm{BP}$ & $5 \% \mathrm{BP}$ & $15 \% \mathrm{BP}$ & & Grain & $\mathrm{BP}$ & Grain $\times \mathrm{BP}$ \\
\hline \multicolumn{9}{|l|}{ Yield, kg/d } \\
\hline Actual milk & 45.6 & 46.0 & 48.1 & 47.4 & 1.23 & 0.05 & 0.85 & 0.55 \\
\hline $4 \% \mathrm{FCM}$ & 37.9 & 40.5 & 41.2 & 40.8 & 1.14 & 0.04 & 0.18 & 0.08 \\
\hline ECM & 40.8 & 43.4 & 44.4 & 43.9 & 1.17 & 0.02 & 0.23 & 0.09 \\
\hline Fat & 1.3 & 1.47 & 1.48 & 1.47 & 0.056 & 0.06 & 0.07 & 0.06 \\
\hline Protein & 1.31 & 1.31 & 1.39 & 1.37 & 0.033 & 0.03 & 0.74 & 0.65 \\
\hline Lactose & 2.1 & 2.11 & 2.23 & 2.19 & 0.052 & 0.03 & 0.71 & 0.61 \\
\hline \multicolumn{9}{|l|}{ Milk composition, $\%$} \\
\hline Fat & 2.77 & 3.19 & 3.08 & 3.12 & 0.104 & 0.47 & 0.05 & 0.10 \\
\hline Protein & 2.87 & 2.86 & 2.89 & 2.88 & 0.019 & 0.07 & 0.56 & 0.63 \\
\hline Lactose & 4.61 & 4.58 & 4.64 & 4.63 & 0.039 & 0.05 & 0.34 & 0.68 \\
\hline Fat:protein & 1.00 & 1.12 & 1.07 & 1.08 & 0.038 & 0.7 & 0.05 & 0.13 \\
\hline MUN, mg/dL & 16.0 & 15.2 & 14.8 & 15.7 & 0.504 & 0.43 & 0.93 & 0.11 \\
\hline \multicolumn{9}{|l|}{ Feed conversion efficiencies } \\
\hline Actual milk/DMI & 1.72 & 1.77 & 1.73 & 1.72 & 0.046 & 0.62 & 0.6 & 0.47 \\
\hline $\mathrm{FCM} / \mathrm{DMI}$ & 1.46 & 1.55 & 1.43 & 1.54 & 0.048 & 0.62 & 0.04 & 0.83 \\
\hline $\mathrm{ECM} / \mathrm{DMI}$ & $1.54^{\mathrm{b}}$ & $1.66^{\mathrm{a}}$ & 1.59 & 1.6 & 0.035 & 0.96 & 0.04 & 0.05 \\
\hline HEE output/HEE input ${ }^{3}$ & $0.692^{\mathrm{b}}$ & $0.928^{\mathrm{a}}$ & 0.614 & 0.775 & 0.016 & $<0.01$ & $<0.01$ & $<0.01$ \\
\hline HEP output/HEP input ${ }^{3}$ & 0.639 & 0.725 & 0.618 & 0.678 & 0.018 & 0.03 & $<0.01$ & 0.41 \\
\hline
\end{tabular}

$\overline{\mathrm{a}, \mathrm{b}}$ Within grain, means of BP levels with different superscripts differ $(P \leq 0.05)$.

${ }^{1}$ Experimental diets were a barley-based diet with sugar beet pulp (BP) at $5 \%$ of dietary DM; a barley-based diet with BP at $15 \%$ of dietary DM; a corn-based diet with BP at $5 \%$ of dietary DM; and a corn-based diet with BP at $15 \%$ of dietary DM.

${ }^{2} \mathrm{Grain}=$ effect of grain sources; $\mathrm{BP}=$ effect of beet pulp level; Grain $\times \mathrm{BP}=$ interaction of grain sources and beet pulp level.

${ }^{3}$ Human-edible protein (HEP) and human-edible energy (HEE) were calculated according to recommendations by Wilkinson (2011). 
lahi et al., 2017). Therefore, the values reported in the present study are likely a good indication of potential treatment effects on ruminal acidity. However, to have a better comparison of treatment effects on ruminal fermentation profile, more comprehensive data need to be obtained by measuring ruminal $\mathrm{pH}$ at multiple time points after feeding, or by continuous measurement of ruminal $\mathrm{pH}$ via indwelling probe.

The substitution of BP for both barley and corn grains increased ruminal $\mathrm{pH}$. Because treatment did not affect chewing and sorting behaviors, the mode of action of $\mathrm{BP}$ on improving ruminal $\mathrm{pH}$ might be related to other mentioned mechanisms, such as shifting of microbial fermentation to a lower acid load by the change in VFA (Hall and Herejk, 2001) and the high buffering capacity and $\mathrm{K}$ content of BP (Jasaitis et al., 1987; NRC, 2001). In agreement with our results, other studies, such as those by Mahjoubi et al. (2009), Mojtahedi and Mesgaran (2011), and Shahmoradi et al. (2015), have reported that partial substitution of BP for barley grain improved ruminal $\mathrm{pH}$ in dairy cows. However, other studies found no detectable difference in ruminal $\mathrm{pH}$ when BP was substituted for corn or a mixture of corn and barley grains (Alamouti et al., 2014; Dann et al., 2014). In a meta-analysis by Münnich et al. (2017), the effects of BP inclusion on ruminal $\mathrm{pH}$ were found to depend on DM intake and proportion of BP included in the diet, where the inclusion of $\mathrm{BP}$ affected ruminal $\mathrm{pH}$ more as DM intake increased and as the level of BP inclusion increased.

In the present study, the substitution of BP for barley grain resulted in increased acetate concentration in the rumen, but a similar response was not observed when $\mathrm{BP}$ was substituted for corn. One explanation for the result could be related to the different nature of starch digestion in the rumen for barley and corn grain (Mills et al., 1999a; Nasrollahi and Khorvash, 2014). Mills et al. (1999a) demonstrated that barley grain promoted propionate production due to a greater rate and amount of ruminal starch degradation, whereas a slower ruminal degradation rate for corn grain promoted relatively more acetate production. Therefore, a substrate such as BP, which is known to stimulate acetate-producing bacteria (Strobel and Russell, 1986; Abo-Zeid et al., 2017), can be effective for increasing ruminal acetate concentration when substituted for barley grain with low potential of acetate production. In agreement with this explanation, a meta-analysis showed that the effect of moderate levels of BP (10-20\% of DM) on ruminal acetate production is diet-dependent, and BP inclusion can cause greater acetate production only in highconcentrate diets with a high potential of propionate production (Münnich et al., 2017).
In the present study, the substitution of BP for grain improved milk fat content and production as well as FCE for FCM production. The improvement of milk fat was expected, as it has been reported previously (Mahjoubi et al., 2009), and increased milk fat production in the present study was supported by greater ruminal $\mathrm{pH}$ and acetate production. Indeed, acetate is one of the important precursors for de novo milk fat synthesis in the mammary gland (Palmquist et al., 1969; Clegg et al., 2001), and improving ruminal $\mathrm{pH}$ can prevent induction of milk fat depression (Martel et al., 2011). Also, the average milk fat percentage in the present study was 3.04, which was was natural considering the high-producing dairy cows used (NRC, 2001). However, the improvement in FCE for FCM production observed in the present study was different from the findings of previous studies, where this parameter was not affected by substituting BP for grains (Voelker and Allen, 2003a; Pang et al., 2018; Shi et al., 2019). One of the considerable differences between the present study and previous ones is the use of a high-concentrate diet $(65 \%$ vs. $45-50 \%$ ). It is possible that the diets with a high amount of concentrate and low amount of forage can increase the passage of starch from the rumen to the intestine, which has a limited ability to digest the high amount of starch (Mills et al., 1999b). This can lead to inefficient digestion (Mills et al., 1999b; Reynolds, 2006; Fredin et al., 2015) and decrease feed efficiency, and in this condition, the substitution of BP for part of the grain can eliminate the side effects of high-starch feeding and improve feed efficiency.

The present study demonstrated an interaction between grain source and BP level for the result of FCE for ECM production, in which the substitution of $\mathrm{BP}$ for barley, but not corn, improved FCE for ECM production. Similarly, the FCE for HEE was greater when $\mathrm{BP}$ was substituted for barley in the diet. As reported previously, the level of potentially digestible NDF in BP is greater than in barley grain (30.9 and 19.7\% of DM; Franco et al., 2017). Therefore, substitution of BP for barley grain is a substitution of a highly digestible NDF for a low-digestible NDF, which potentially can increase total-tract NDF digestibility (Pang et al., 2018). This point may not completely explain the condition of the present study, because our measure of NDF digestibility only numerically increased when BP was substituted for barley grain.

Although not measured in the present study, another explanation for improved FCE for ECM production with BP substitution for barley could be related to decreased inflammation resulting from acidosis. Indeed, diets with barley grain as a primary ingredient have been shown to increase inflammatory responses (Em- 
manuel et al., 2008), which can adversely affect feed utilization efficiency (Khiaosa-ard and Zebeli, 2014). Therefore, replacing some portion of barley grain with $\mathrm{BP}$, as in the present study, could ameliorate this risk and improve production efficiency. Measurements related to inflammation will be required in future studies to determine whether productive effects are related only to improved ruminal fermentation, or whether productive effects are also related to the prevention of ruminal acidosis and associated inflammatory outcomes.

Using HE grains as animal feed has been a worldwide trend for supporting the energy requirements of highproducing cows but has affected the sustainability of dairy production. The use of HE grains for biodiesel production has made $\mathrm{HE}$ grains an even more valuable resource. Therefore, strategies that decrease HE grain consumption in ruminant nutrition can improve the sustainability of dairy farming. In the present study, dietary HEP and HEE were decreased by substituting BP for grain, and this agrees with previous reports (Ertl et al., 2015b; Münnich et al., 2018; Pang et al., 2018). Our data demonstrate that productive efficiency can be increased by decreasing dietary HEE and HEP, but these increases were most pronounced when $\mathrm{BP}$ was substituted for barley, rather than corn. Therefore, the partial replacement of barley with BP in dairy cow diets can improve the sustainability of milk production from high-producing dairy cows fed a high-concentrate diet.

\section{CONCLUSIONS}

Substitution of BP for grains (barley or corn) in the diet of dairy cows fed high-concentrate diets decreased intake of starch, HEP, and HEE and improved ruminal $\mathrm{pH}$ (measured $4 \mathrm{~h}$ after feeding), milk fat production, and the FCE for FCM production. When BP was substituted for barley grain, ruminal acetate concentration increased and the FCE for ECM production increased, but similar responses were not observed when $\mathrm{BP}$ was substituted for corn. Also, the improvement in FCE for HEE was greater when BP was substituted for barley. Future studies are warranted, to discover the mechanism behind different responses observed in the present study when BP is substituted for barley or corn. Measuring the rate and site of carbohydrate digestion and metabolism, as well as continuous monitoring of ruminal $\mathrm{pH}$ and the associated inflammatory responses, may be of interest in this regard.

\section{ACKNOWLEDGMENTS}

This manuscript is contribution no. 95822654 from the Iran National Science Foundation (Tehran, Iran).
The authors express their appreciation to the managers and staff of FKA Agriculture and Animal Husbandry (Isfahan, Iran) for their kind assistance and diligent animal care. The authors acknowledge Lucas Krueger (Agri-King Inc., Fulton, IL) for revision in English. The authors have not stated any conflicts of interest.

\section{REFERENCES}

Abo-Zeid, H. M., H. M. El-Zaiat, A. S. Morsy, M. Attia, M. F. A. Abaza, and S. M. A. Sallam. 2017. Effects of replacing dietary maize grains with increasing levels of sugar beet pulp on rumen fermentation constituents and performance of growing buffalo calves. Anim. Feed Sci. Technol. 234:128-138. https://doi.org/10 .1016/j.anifeedsci.2017.09.011.

Alamouti, A. A., M. Alikhani, G. R. Ghorbani, A. Teimouri-Yansari, and M. Bagheri. 2014. Response of early lactation Holstein cows to partial replacement of neutral detergent soluble fibre for starch in diets varying in forage particle size. Livest. Sci. 160:60-68. https:/ /doi.org/10.1016/j.livsci.2013.12.009.

Alamouti, A. A., M. Alikhani, G. R. Ghorbani, and Q. Zebeli. 2009. Effects of inclusion of neutral detergent soluble fibre sources in diets varying in forage particle size on feed intake, digestive processes, and performance of mid-lactation Holstein cows. Anim. Feed Sci. Technol. 154:9-23. https://doi.org/10.1016/j.anifeedsci .2009.07.002.

Albornoz, R. I., and M. S. Allen. 2018. Highly fermentable starch at different diet starch concentrations decreased feed intake and milk yield of cows in the early postpartum period. J. Dairy Sci. 101:8902-8915. https://doi.org/10.3168/jds.2018-14843.

Allen, M. S. 2000. Effects of diet on short-term regulation of feed intake by lactating dairy cattle. J. Dairy Sci. 83:1598-1624. https:// doi.org/10.3168/jds.S0022-0302(00)75030-2.

AOAC International. 2006. Official Methods of Analysis. 18th ed AOAC International, Arlington, VA.

ASAE (American Society of Agricultural Engineers). 1995. Method of Determining and Expressing Fineness of Feed Material by Sieving: Method S424.1. Page 461 in ASAE Standards 1995. ASAE, St. Joseph, MI.

Beauchemin, K. A., W. Z. Yang, and L. M. Rode. 2003. Effects of particle size of alfalfa-based dairy cow diets on chewing activity, ruminal fermentation, and milk production. J. Dairy Sci. 86:630-643. https://doi.org/10.3168/jds.S0022-0302(03)73641-8.

Bender, R. W., D. E. Cook, and D. K. Combs. 2016. Comparison of in situ versus in vitro methods of fiber digestion at 120 and 288 hours to quantify the indigestible neutral detergent fiber fraction of corn silage samples. J. Dairy Sci. 99:5394-5400. https://doi.org/ 10.3168/jds.2015-10258.

Broderick, G. A., and J. H. Kang. 1980. Automated simultaneous determination of ammonia and total amino acids in rumen fluid and in vitro media. J. Dairy Sci. 63:64-75. https://doi.org/10.3168/jds .S0022-0302(80)82888-8.

Calsamiglia, S., A. Ferret, and M. Devant. 2002. Effects of pH and $\mathrm{pH}$ fluctuations on microbial fermentation and nutrient flow from a dual-flow continuous culture system. J. Dairy Sci. 85:574-579. https://doi.org/10.3168/jds.S0022-0302(02)74111-8.

Cassidy, E. S., P. C. West, J. S. Gerber, and J. A. Foley. 2013. Redefining agricultural yields: From tonnes to people nourished per hectare. Environ. Res. Lett. 8:034015. https://doi.org/10.1088/ 1748-9326/8/3/034015.

Clegg, R. A., M. C. Barber, L. Pooley, I. Ernens, Y. Larondelle, and M. T. Travers. 2001. Milk fat synthesis and secretion: Molecular and cellular aspects. Livest. Prod. Sci. 70:3-14. https://doi.org/10 .1016/S0301-6226(01)00194-4.

Cooke, K. M., J. K. Bernard, and J. W. West. 2008. Performance of dairy cows fed annual ryegrass silage and corn silage with steam flaked or ground corn. J. Dairy Sci. 91:2417-2422. https://doi.org/ $10.3168 /$ jds.2007-0715. 
Dann, H. M., H. A. Tucker, K. W. Cotanch, P. D. Krawczel, C. S. Mooney, R. J. Grant, and T. Eguchi. 2014. Evaluation of lower-starch diets for lactating Holstein dairy cows. J. Dairy Sci. 97:7151-7161. https://doi.org/10.3168/jds.2014-8341.

Emmanuel, D. G. V., S. M. Dunn, and B. N. Ametaj. 2008. Feeding high proportions of barley grain stimulates an inflammatory response in dairy cows. J. Dairy Sci. 91:606-614. https://doi.org/10 $.3168 / \mathrm{jds} .2007-0256$.

Ertl, P., W. Knaus, B. U. Metzler-Zebeli, F. Klevenhusen, R. KhiaosaArd, and Q. Zebeli. 2015a. Substitution of common concentrates with by-products modulated ruminal fermentation, nutrient degradation, and microbial community composition in vitro. J. Dairy Sci. 98:4762-4771. https://doi.org/10.3168/jds.2014-9063.

Ertl, P., Q. Zebeli, W. Zollitsch, and W. Knaus. 2015b. Feeding of byproducts completely replaced cereals and pulses in dairy cows and enhanced edible feed conversion ratio. J. Dairy Sci. 98:1225-1233. https://doi.org/10.3168/jds.2014-8810.

Esmaeili, M., M. Khorvash, G. R. Ghorbani, S. M. Nasrollahi, and M. Saebi. 2016. Variation of TMR particle size and physical characteristics in commercial Iranian Holstein dairies and effects on eating behaviour, chewing activity, and milk production. Livest. Sci. 191:22-28. https://doi.org/10.1016/j.livsci.2016.07.003.

Fernando, S. C., H. T. Purvis II, F. Z. Najar, L. O. Sukharnikov, C. R. Krehbiel, T. G. Nagaraja, B. A. Roe, and U. DeSilva. 2010. Rumen microbial population dynamics during adaptation to a highgrain diet. Appl. Environ. Microbiol. 76:7482-7490. https:// doi.org/10.1128/AEM.00388-10.

Fox, D. G., T. P. Tylutki, K. J. Czymmek, C. N. Rasmussen, and V. M. Durbal. 2000. Development and application of the Cornell University nutrient management planning system. Pages 167-179 in Proc. Cornell Nutr. Conf. Feed Manuf., Rochester, NY. Cornell University, Ithaca, NY.

Franco, M. O., S. J. Krizsan, M. Ramin, R. Spörndly, and P. Huhtanen. 2017. In vitro evaluation of agro-industrial by-products replacing soybean meal in two different basal diets for ruminants. Pages 54-59 in Proc. 8th Nordic Feed Sci. Conf. The Swedish University of Agricultural Sciences, Uppsala, Sweden.

Fredin, S. M., L. F. Ferraretto, M. S. Akins, S. J. Bertics, and R. D. Shaver. 2015. Effects of corn-based diet starch content and corn particle size on lactation performance, digestibility, and bacterial protein flow in dairy cows. J. Dairy Sci. 98:541-553. https://doi .org/10.3168/jds.2016-11559.

Grant, R. J., and D. R. Mertens. 1992. Influence of buffer $\mathrm{pH}$ and raw corn starch addition on in vitro fiber digestion kinetics. J. Dairy Sci. 75:2762-2768. https://doi.org/10.3168/jds.S0022 $-0302(92) 78039-4$.

Hall, M. B., and C. Herejk. 2001. Differences in yields of microbial crude protein from in vitro fermentation of carbohydrates. J. Dairy Sci. 84:2486-2493. https://doi.org/10.3168/jds.S0022 $-0302(01) 74699-1$.

Hashemzadeh-Cigari, F., M. Khorvash, G. R. Ghorbani, M. Kadivar, A. Riasi, and Q. Zebeli. 2014. Effects of supplementation with a phytobiotics-rich herbal mixture on performance, udder health, and metabolic status of Holstein cows with various levels of milk somatic cell counts. J. Dairy Sci. 97:7487-7497. https://doi.org/10 $.3168 /$ jds.2014-7989.

Iranian Council of Animal Care. 1995. Guide to the Care and Use of Experimental Animals, Vol. 1 Isfahan University of Technology, Isfahan, Iran.

Jasaitis, D. K., J. E. Wohlt, and J. L. Evans. 1987. Influence of feed ion content on buffering capacity of ruminant feedstuffs in vitro. J. Dairy Sci. 70:1391-1403. https://doi.org/10.3168/jds.S0022 -0302(87)80161-3.

Kahyani, A., G. R. Ghorbani, M. Alikhani, E. Ghasemi, A. SadeghiSefidmazgi, and S. M. Nasrollahi. 2019. Adjusting for 30-hour undigested neutral detergent fiber in substitution of wheat straw and beet pulp for alfalfa hay and corn silage in the diet of highproducing cows. J. Dairy Sci. 102:7026-7037. https://doi.org/10 .3168/jds.2018-15740.

Kargar, S., G. R. Ghorbani, M. Khorvash, A. Sadeghi-Sefidmazgi, and D. J. Schingoethe. 2014. Reciprocal combinations of barley and corn grains in oil-supplemented diets: Feeding behavior and milk yield of lactating cows. J. Dairy Sci. 97:7001-7011. https://doi .org/10.3168/jds.2013-7850.

Khiaosa-ard, R., and Q. Zebeli. 2014. Cattle's variation in rumen ecology and metabolism and its contributions to feed efficiency. Livest. Sci. 162:66-75. https://doi.org/10.1016/j.livsci.2014.01.005.

Kononoff, P. J., A. J. Heinrichs, and D. R. Buckmaster. 2003. Modification of the Penn State Forage and Total Mixed Ration Particle Separator and the effects of moisture content on its measurements. J. Dairy Sci. 86:1858-1863. https://doi.org/10.3168/jds.S0022 -0302(03)73773-4.

Lammers, B. P., D. R. Buckmaster, and A. J. Heinrichs. 1996. A simple method for the analysis of particle sizes of forage and total mixed rations. J. Dairy Sci. 79:922-928. https://doi.org/10.3168/ jds.S0022-0302(96)76442-1.

Leonardi, C., and L. E. Armentano. 2003. Effect of quantity, quality and particle length of alfalfa hay on selective consumption by dairy cows. J. Dairy Sci. 86:557-564. https://doi.org/10.3168/jds.S0022 -0302(03)73634-0.

Mahjoubi, E., H. Amanlou, D. Zahmatkesh, M. G. Khan, and N. Aghaziarati. 2009. Use of beet pulp as a replacement for barley grain to manage body condition score in over-conditioned late lactation cows. Anim. Feed Sci. Technol. 153:60-67. https://doi.org/ 10.1016/j.anifeedsci.2009.06.009.

Mansfield, H. R., M. D. Stern, and D. E. Otterby. 1994. Effects of beet pulp and animal by-products on milk yield and in vitro fermentation by rumen microorganisms. J. Dairy Sci. 77:205-216. https:// doi.org/10.3168/jds.S0022-0302(94)76943-5.

Marounek, M., S. Bartos, and P. Brezina. 1985. Factors influencing the production of volatile fatty acids from hemicellulose, pectin and starch by mixed culture of rumen microorganisms. Z. Tierphysiol Tierernahr. Futtermittelkd. 53:50-58. https://doi.org/10.1111/j .1439-0396.1985.tb00006.x.

Martel, C. A., E. C. Titgemeyer, L. K. Mamedova, and B. J. Bradford. 2011. Dietary molasses increases ruminal $\mathrm{pH}$ and enhances ruminal biohydrogenation during milk fat depression. J. Dairy Sci 94:3995-4004. https://doi.org/10.3168/jds.2011-4178.

McBurney, M. I., P. J. Van Soest, and L. E. Chase. 1983. Cation exchange capacity and buffering capacity of neutral detergent fibres. J. Sci. Food Agric. 34:910-916. https://doi.org/10.1002/jsfa .2740340903 .

Mertens, D. R. 1997. Creating a system for meeting the fiber requirements of dairy cows. J. Dairy Sci. 80:1463-1481. https://doi.org/ 10.3168/jds.S0022-0302(97)76075-2.

Mills, J. A. N., J. France, and J. Dijkstra. 1999a. A review of starch digestion in the lactating dairy cow and proposals for a mechanistic model. 1. Dietary starch characterisation and ruminal starch digestion. J. Anim. Feed Sci. 8:291-340. https://doi.org/10.22358/ jafs $/ 68938 / 1999$.

Mills, J. A. N., J. France, and J. Dijkstra. 1999b. A review of starch digestion in the lactating dairy cow and proposals for a mechanistic model: 2. Postruminal starch digestion and small intestinal glucose absorption. J. Anim. Feed Sci. 8:451-481. https://doi.org/ $10.22358 / \mathrm{jafs} / 69123 / 1999$.

Mojtahedi, M., and M. D. Mesgaran. 2011. Effects of the inclusion of dried molassed sugar beet pulp in a low-forage diet on the digestive process and blood biochemical parameters of Holstein steers. Livest. Sci. 141:95-103. https://doi.org/10.1016/j.livsci.2011.05.009.

Münnich, M., R. Khiaosa-ard, F. Klevenhusen, A. Hilpold, A. KholParisini, and Q. Zebeli. 2017. A meta-analysis of feeding sugar beet pulp in dairy cows: Effects on feed intake, ruminal fermentation, performance, and net food production. Anim. Feed Sci. Technol. 224:78-89. https://doi.org/10.1016/j.anifeedsci.2016.12.015.

Münnich, M., F. Klevenhusen, and Q. Zebeli. 2018. Feeding of molassed sugar beet pulp instead of maize enhances net food production of high-producing Simmental cows without impairing metabolic health. Anim. Feed Sci. Technol. 241:75-83. https://doi.org/10 .1016/j.anifeedsci.2018.04.018.

Naderi, N. 2014. Effects of substitution of dried sugar beet pulp for corn silage on performance and chewing behavior of high produc- 
ing dairy cows. MS Thesis. Department of Animal Science, Isfahan University of Technology, Isfahan, Iran.

Nasrollahi, S. M., and M. Khorvash. 2014. Carbohydrates in Dairy Cow Nutrition. 1st ed. Khotan Publication, Tehran, Iran.

Nasrollahi, S. M., M. Khorvash, G. R. Ghorbani, A. Teimouri-Yansari, A. Zali, and Q. Zebeli. 2012. Grain source and marginal changes in forage particle size modulate digestive processes and nutrient intake of dairy cows. Animal 6:1237-1245. https://doi.org/10.1017/ S1751731112000122.

Nasrollahi, S. M., A. Zali, G. R. Ghorbani, M. Khani, H. Maktabi, and K. A. Beauchemin. 2019. Effects of increasing diet fermentability on intake, digestion, rumen fermentation, blood metabolites and milk production of heat-stressed dairy cows. Animal 13:2527-2535. https://doi.org/10.1017/S1751731119001113.

Nasrollahi, S. M., A. Zali, G. R. Ghorbani, M. Moradi Shahrbabak, and M. Heydari Soltan Abadi. 2017. Variability in the susceptibility to acidosis among high producing mid-lactation dairy cows is associated with rumen $\mathrm{pH}$, fermentation, feed intake, sorting activity, and milk fat percentage. Anim. Feed Sci. Technol. 228:72-82. https://doi.org/10.1016/j.anifeedsci.2017.03.007.

Nordlund, K. V., and E. F. Garrett. 1994. Rumenocentesis: A technique for the diagnosis of subacute rumen acidosis in dairy herds. Bov. Pract. 28:109-112.

NRC. 2001. Nutrient Requirement of Dairy Cattle. 7th rev. ed. Natl. Acad. Sci., Washington, DC.

Palmquist, D. L., C. L. Davis, R. E. Brown, and D. S. Sachan. 1969. Availability and metabolism of various substrates in ruminants. V. Entry rate into the body and incorporation into milk fat of B-hydroxybutyrate. J. Dairy Sci. 52:633-638. https://doi.org/10 .3168/jds.S0022-0302(69)86620-8.

Pang, D., T. Yan, E. Trevisi, and S. J. Krizsan. 2018. Effect of grainor by-product-based concentrate fed with early- or late-harvested first-cut grass silage on dairy cow performance. J. Dairy Sci. 101:7133-7145. https://doi.org/10.3168/jds.2018-14449.

Razzaghi, A., R. Valizadeh, M. H. Ghaffari, and A. F. Brito. 2020. Liquid molasses interacts with buffers to affect ruminal fermentation, milk fatty acid profile, and milk fat synthesis in dairy cows fed high-concentrate diets. J. Dairy Sci. 103:4327-4339. https:// doi.org/10.3168/jds.2019-17169

Reynolds, C. K. 2006. Production and metabolic effects of site of starch digestion in dairy cattle. Anim. Feed Sci. Technol. 130:7894. https://doi.org/10.1016/j.anifeedsci.2006.01.019.

SAS. 2002. User's Guide: Statistics, Version 9.1. SAS Institute, Inc., Cary, NC.

Shahmoradi, A., M. Alikhani, A. Riasi, G. R. Ghorbani, and M. H. Ghaffari. 2015. Effects of partial replacement of barley grain with beet pulp on performance, ruminal fermentation and plasma concentration of metabolites in transition dairy cows. J. Anim. Physi- ol. Anim. Nutr. (Berl.) 100:178-188. https://doi.org/10.1111/jpn .12305 .

Shi, W., C. E. Knoblock, K. V. Murphy, T. C. Bruinjé, I. Yoon, D. J. Ambrose, and M. Oba. 2019. Effects of supplementing a Saccharomyces cerevisiae fermentation product during the periparturient period on performance of dairy cows fed fresh diets differing in starch content. J. Dairy Sci. 102:3082-3096. https://doi.org/10 $.3168 /$ jds.2018-15307.

Silveira, C., M. Oba, K. A. Beauchemin, and J. Helm. 2007. Effect of grains differing in expected ruminal fermentability on productivity of lactating dairy cows. J. Dairy Sci. 90:2852-2859. https://doi .org/10.3168/jds.2006-649.

Strobel, H. J., and J. B. Russell. 1986. Effect of pH and energy spilling on bacterial protein synthesis by carbohydrate-limited cultures of mixed rumen bacteria. J. Dairy Sci. 69:2941-2947. https://doi .org/10.3168/jds.S0022-0302(86)80750-0.

Townshend, A. 1995. Encyclopedia of Analytical Science. Academic Press, London, UK.

Van Soest, P. J., J. B. Robertson, and B. A. Lewis. 1991. Methods for dietary fiber, neutral detergent fiber, and nonstarch polysaccharides in relation to animal nutrition. J. Dairy Sci. 74:3583-3597. https://doi.org/10.3168/jds.S0022-0302(91)78551-2.

Voelker, J. A., and M. S. Allen. 2003a. Pelleted beet pulp substituted for high-moisture corn: 1. Effects on feed intake, chewing behavior, and milk production of lactating dairy cows. J. Dairy Sci. 86:35423552. https://doi.org/10.3168/jds.S0022-0302(03)73959-9.

Voelker, J. A., and M. S. Allen. 2003b. Pelleted beet pulp substituted for high-moisture corn: 3 . Effects on ruminal fermentation, $\mathrm{pH}$, and microbial protein efficiency in lactating dairy cows. J. Dairy Sci. 86:3562-3570. https://doi.org/10.3168/jds.S0022-0302(03)73961 -7 .

Wilkinson, J. M. 2011. Re-defining efficiency of feed use by livestock. Animal 5:1014-1022. https://doi.org/10.1017/S175173111100005X.

Wilson, R. C., T. R. Overton, and J. H. Clark. 1998. Effects of Yucca shidigera extract and soluble protein on performance of cows and concentrations of urea nitrogen in plasma and milk. J. Dairy Sci. 81:1022-1027. https://doi.org/10.3168/jds.S0022-0302(98)75664 $-4$.

Zebeli, Q., J. R. Aschenbach, M. Tafaj, J. Boguhn, B. N. Ametaj, and W. Drochner. 2012. Invited review: Role of physically effective fiber and estimation of dietary fiber adequacy in high-producing dairy cattle. J. Dairy Sci. 95:1041-1056. https://doi.org/10.3168/ jds.2011-4421.

Zhu, L., C. Jones, Q. Guo, L. Lewis, C. R. Stark, and S. Alavi. 2016. An evaluation of total starch and starch gelatinization methodologies in pelleted animal feed. J. Anim. Sci. 94:1501-1507. https:// doi.org/10.2527/jas.2015-9822. 